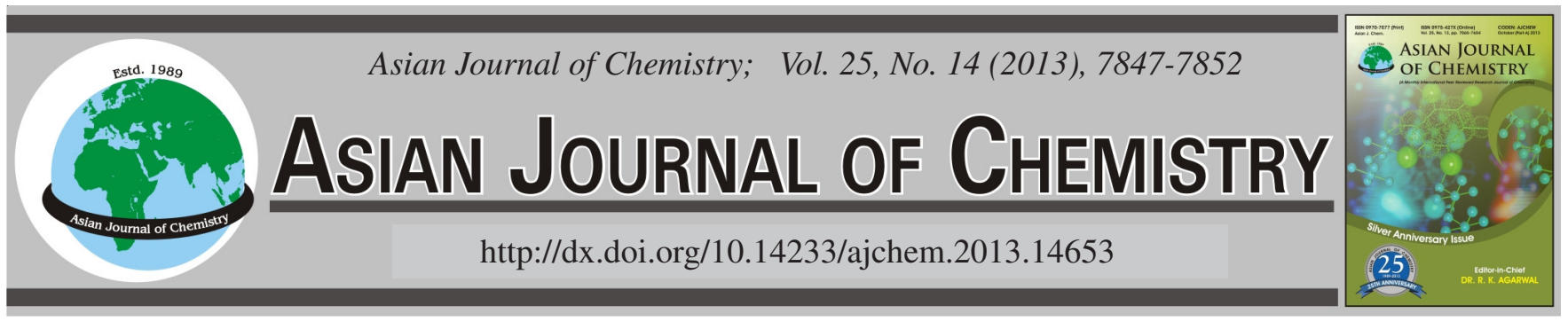

\title{
Chiral Separation of Lamivudine by Capillary Zone Electrophoresis
}

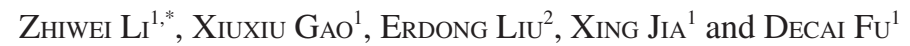

${ }^{1}$ College of Chemical and Pharmaceutical Engineering, Hebei University of Science and Technology, Shijiazhuang 050018, P.R. China ${ }^{2}$ College of Chemistry and Chemical Engineering, Qufu Normal University, Qufu 273165, P.R. China

*Corresponding author: Tel: +86 311 88632202; E-mail: lizhiwei@ hebust.edu.cn

(Received: 8 October 2012;

Accepted: 20 July 2013)

AJC-13824

\begin{abstract}
In this work, the application of capillary electrophoresis in chiral technology was studied for lamivudine. A new capillary zone electrophoresis method was established to chiral separation of lamivudine. It was separated with an untreated fused silica capillary (75 $\mu \mathrm{m}$ I.D., effective length is $55 \mathrm{~cm}) .40 \mathrm{mmol} / \mathrm{L}$ sodium dihydrogen phosphate and $40 \mathrm{mg} / \mathrm{mL} \mathrm{HP}-\beta$-cyclodextrin $(\mathrm{pH}=3.1)$ was running buffer solution at the detection wavelength of $270 \mathrm{~nm}$. Separation voltage was $15 \mathrm{kv}$ and the injection time of sample was $15 \mathrm{~s}$. The separation of both enantiomers of lamivudine could be achieved baseline resolution. The calibration curve for lamivudine optical isomers exhibited an excellent linear relationship in concentration range of 0.0625 to $1 \mathrm{mg} / \mathrm{mL}$. The precision was less than $2 \%$. The average recovery was $99.71 \%$ and $100.12 \%$. In addition, the detection limit was $1.25 \mu \mathrm{g} / \mathrm{mL}$ for lamivudine and its enantiomer was $2.5 \mu \mathrm{g} / \mathrm{mL}$. The method is simple, rapid and accurate. It can be used for quality control of the enantiomers of lamivudine.
\end{abstract}

Key Words: Lamivudine, Capillary zone electrophoresis, Chiral, Separation.

\section{INTRODUCTION}

Since there are differences in biological activity and toxicity between enantiomers, chiral resolution is an important subject in the development of the enantiomeric drugs ${ }^{1}$. A number of chromatographic and spectroscopic methods have been developed for the analysis of enantiomers. Among the chromatographic methods so far developed, high-performance liquid chromatographic methods based on chiral enantiostationary phases are widely employed for the assays of drug enantiomers in pharmaceutical preparations and biological fluids. However, one column can only separate a limited number of enantiomeric compounds. Recently, capillary electrophoretic methods using a chiral selector as the running buffer additive have been used for the above purposes. The chiral additives so far employed have included polysaccharides, proteins, bile salts and chiral mixed micelles. Cyclodextrin is a polysaccharides with three isomeric forms i.e., $\alpha, \beta, \gamma$-cyclodextrin.

Lamivudine(2',3'-dideoxy-3'-thiacytidine, commonly called 3TC) is marketed by Glaxo Smith Kline with the brand names Zeffix, Heptovir, Epivir and Epivir-HBV. It has been used for treatment of chronic hepatitis B at a lower dose than for treatment of HIV and is used widely as it is well tolerated. The structure of this basic drug is shown in Fig. 1.

In this study, the effects of separation voltage, the concentrations of HP- $\beta$-cyclodextrin and the sepecies, concentration,
$\mathrm{pH}$ of the running buffer were investigated on the lamivudine chiral separation to optimize the proposed method.<smiles>Nc1ccn([C@H]2CS[C@@H](CO)O2)c(=O)n1</smiles><smiles>Nc1ccn([C@H]2CS[C@H](CO)O2)c(=O)n1</smiles>

Fig. 1. A: Lamivudine; B: Enantiomer of lamivudine

\section{EXPERIMENTAL}

Lamivudine and crude drug of lamivudine enantiomers were purchased from Lonzeal Pharmaceuticals Co., Ltd., HP$\beta$-cyclodextrin was obtained from Shandong Binzhou Zhiyuan Bio-Technology Pharmaceutical Co. Ltd., solvents and other chemicals were of analytical grade. Hydrochloric acid $(\mathrm{HCl})$, boric acid $\left(\mathrm{H}_{3} \mathrm{BO}_{3}\right)$, phosphate $\left(\mathrm{H}_{3} \mathrm{PO}_{4}\right)$, sodium dihydrogen phosphate $\left(\mathrm{NaH}_{2} \mathrm{PO}_{4}\right)$, sodium hydroxide $(\mathrm{NaOH})$ were obtained from Tianjin Chemical Reagent mainland. Tripledistilled water was used for the preparation of all solutions. $0.45 \mu \mathrm{m}$ pore size filters was used to filter all the solutions. 
The conditions were as follows: sampling time, $15 \mathrm{~s}$; applied voltage, $15 \mathrm{Kv}$; the detection wavelength, $270 \mathrm{~nm}$. The experiments were carried out at room temperature. The electrolyte was a buffer solution consisting of $40 \mathrm{mmol} / \mathrm{L} \mathrm{NaH}_{2} \mathrm{PO}_{4}$ and $40 \mathrm{mg} / \mathrm{mL}$ HP- $\beta$-cyclodextrin $(\mathrm{pH}=3.1)$.

A new capillary was conditioned by flushing successively with $1.0 \mathrm{~mol} / \mathrm{L} \mathrm{NaOH}$ (overnight), $0.1 \mathrm{~mol} / \mathrm{L} \mathrm{NaOH}(0.5 \mathrm{~h}$ ) and then equilibrated with triple distilled water and running buffer each for $0.5 \mathrm{~h}$ before use. Between each injection, the capillary was rinsed with $0.1 \mathrm{~mol} / \mathrm{L} \mathrm{NaOH}$ (2 min), triple distilled water $(2 \mathrm{~min})$ and with the running buffer $(5 \mathrm{~min})^{2}$.

The experiments were carried out on a laboratory-selfassembled capillary electrophoretic apparatus, equipped with a multiwavelength UV detector. The UV signals were recorded at $270 \mathrm{~nm}$. An untreated fused silica capillary of $55 \mathrm{~cm}$ length and of $75 \mu \mathrm{m}$ i.d. (Hebei Yongnian Optical Fiber Factory, China) was used as a separation tube ${ }^{3}$. A high voltage power supply that can provide voltage from 0 to $30 \mathrm{kV}$ was used to drive the separation.

\section{RESULTS AND DISCUSSION}

Different electrophoresis modes were tested in the experiment. The effect of the separation voltage, the concentrations of HP- $\beta$-cyclodextrin and the sepecies, concentration, $\mathrm{pH}$ of the running buffer were also investigated for the separation of lamivudine by capillary electrophoretic.

Effect of buffer type and concentration: The chemical composition and the concentration of the buffer can affect the baseline stability, peak shape and separation selectivity. In this study, the influence of buffer composition and concentration on the enantiomer separation of lamivudine was investigated. The effects of the two different buffers, $\mathrm{NaH}_{2} \mathrm{PO}_{4}, \mathrm{H}_{3} \mathrm{BO}_{3}$ on the enantiomer separation are shown in Fig. 2. $\mathrm{As} \mathrm{NaH}_{2} \mathrm{PO}_{4}$ can give the excellent baseline enantiomeric separations for the lamivudine, we used $\mathrm{NaH}_{2} \mathrm{PO}_{4}$ as running buffer ${ }^{4}$. The effect of the buffer's concentration upon resolution was investigated in the range of $20-40 \mathrm{~mol} / \mathrm{L}$. When the buffer's concentration is 20 $\mathrm{mmol} / \mathrm{L}$, we can not achieve the purpose of separation (Fig. 3). However, the enantiomeric separation greatly improve with increasing concentration. Moreover, when the buffer's concentration is $40 \mathrm{mmol} / \mathrm{L}$, the enantiomeric separation is better. Hence a $40 \mathrm{mmol} / \mathrm{L} \mathrm{NaH}_{2} \mathrm{PO}_{4}$ concentration was selected for the optimal enantioseparation method.

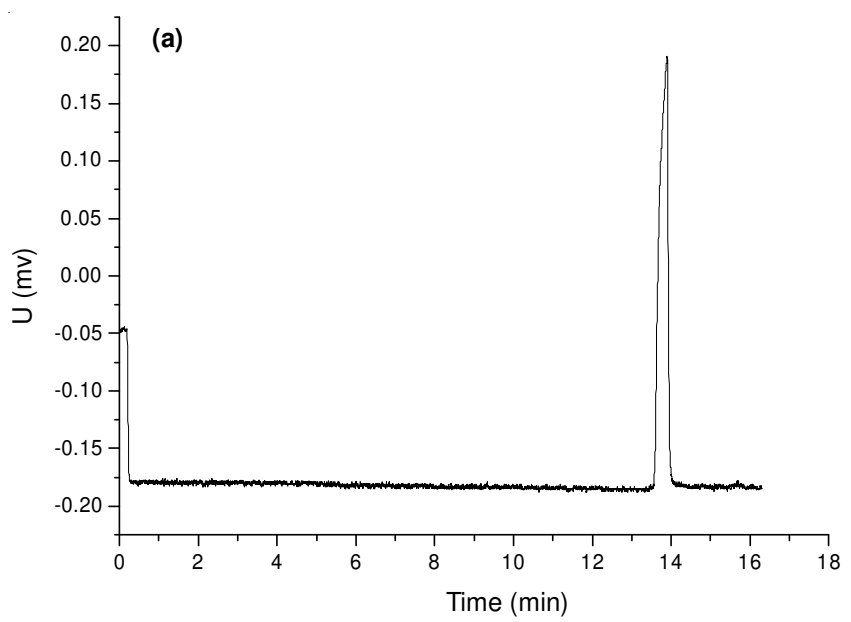

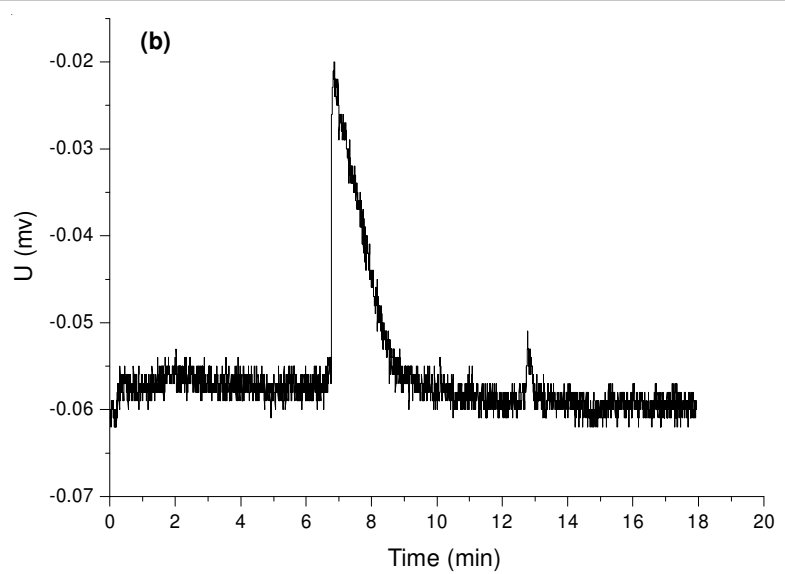

Fig. 2. Effect of buffer type (a) sodium dihydrogen phosphate; (b) boric acid
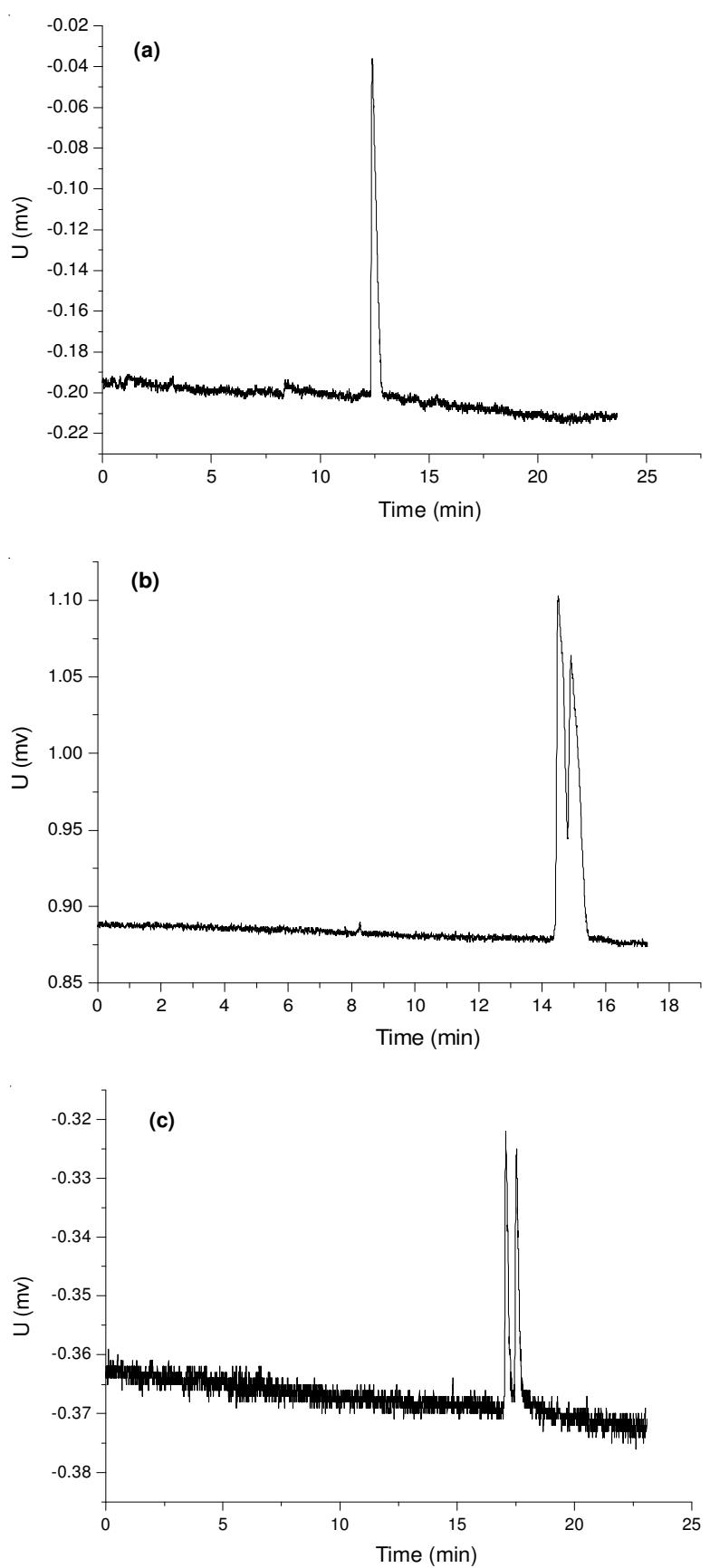

Fig. 3. Effect of buffer concentration (a) $20 \mathrm{mmol} / \mathrm{L}$, (b) $30 \mathrm{mmol} / \mathrm{L}$, (c) $40 \mathrm{mmol} / \mathrm{L}$ 
Effect of pH: Lamivudine molecules exist in two states of molecule (HA) and anion (A-) in aqueous solution. HP- $\beta$ cyclodextrin can form two inclusion complexes with molecular lamivudine enantiomers but not with ionic lamivudine enantiomers. Therefore, $\mathrm{pH}$ can influence the distribution behaviour of lamivudine enantiomers.

As shown in Fig. 4 separation keep nearly unchanged at $\mathrm{pH}<3$, then increase rapidly with rising $\mathrm{pH}$. But an opposite tendency is observed for enantioselectivity. This can be due to the fact that at low $\mathrm{pH}$ value $(\mathrm{pH}<3)$ most extraction is through enantioselective complexation and at higher $\mathrm{pH}$ value $(\mathrm{pH}>3)$ more nonselective partitioning of anion (A-) is occurring. At $\mathrm{pH}<3$, lamivudine molecules hardly dissociate and the amount of molecule (HA) in aqueous phase is much bigger than that of anion (A-). While with the further increase of $\mathrm{pH}(\mathrm{pH}>3)^{5}$, more and more molecular lamivudine enantiomers are dissociated into ionic lamivudine enantiomers in aqueous phase, which leads to partitioning of more molecular lamivudine enantiomers from organic phase to aqueous phase. Therefore, $\mathrm{pH}$ should be kept at 3.08 to carry out the extraction process.

Effect of HP- $\beta$-cyclodextrin concentration: Cyclodex-trin is including $\alpha, \beta, \gamma$-cyclodextrin, of which $\alpha$-cyclodextrin is suitable for low molecular weight compounds, $\beta$-cyclodextrin for medium-sized molecules, $\gamma$-cyclodextrin for the larger molecular weight compounds. Lamivudine is soluble in water, medium-sized molecule, which is consistent with HP- $\beta$ cyclodextrin.
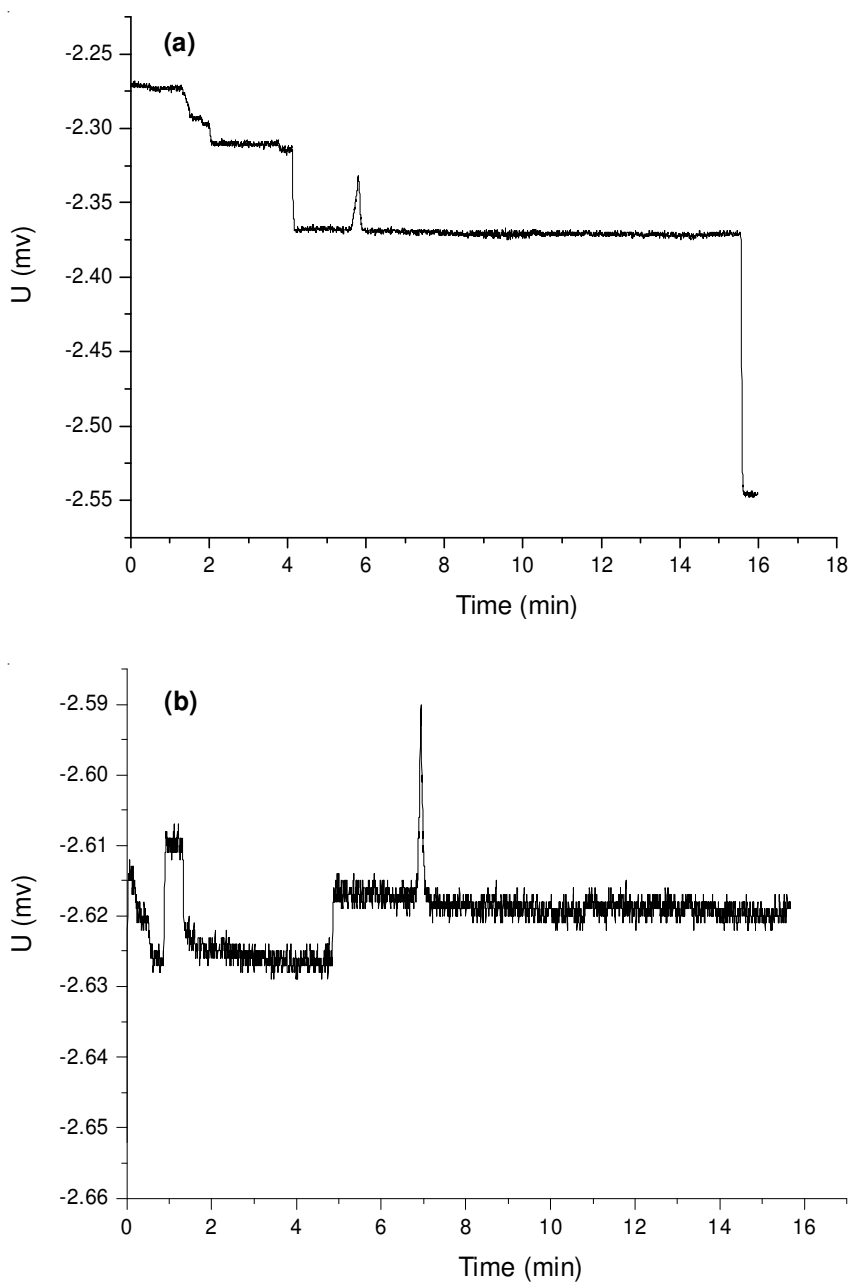
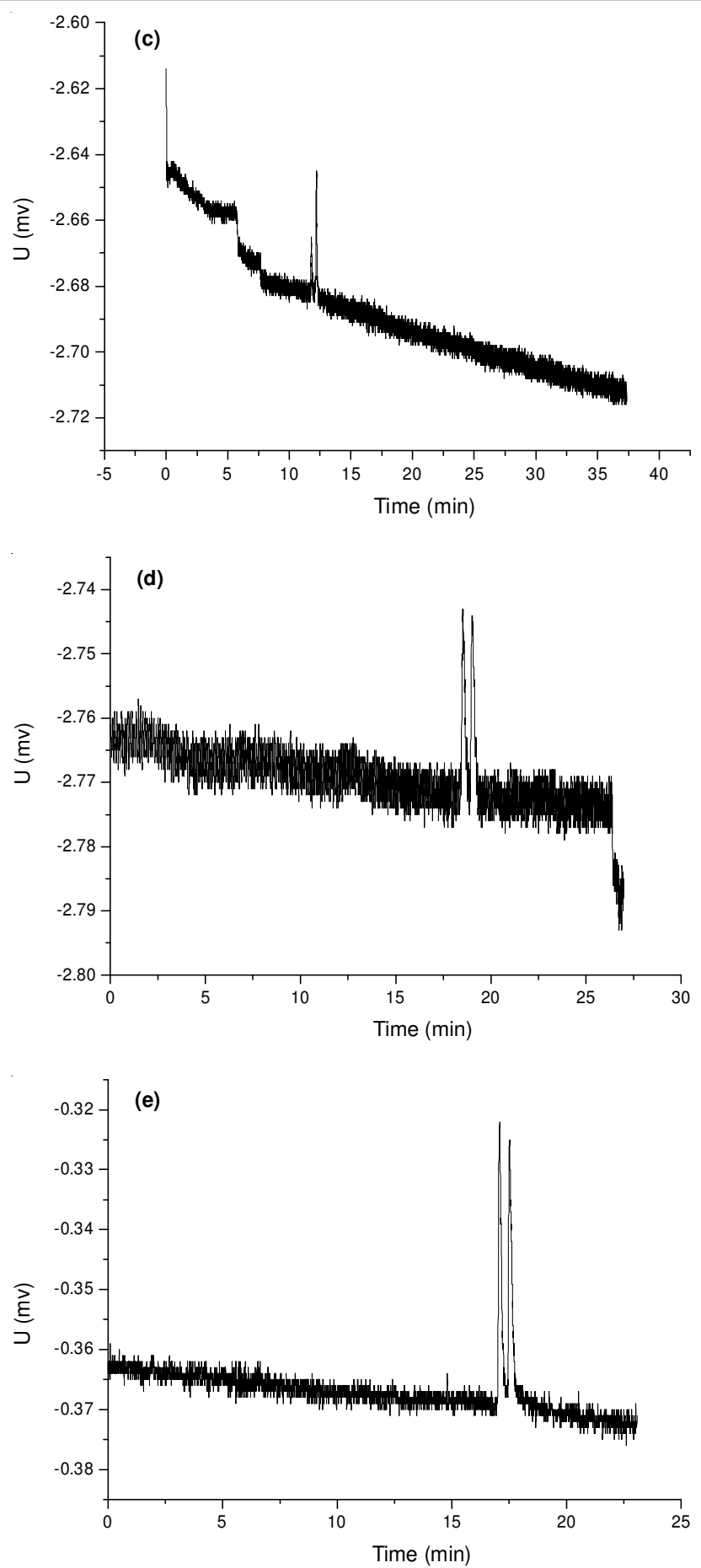

Fig. 4. Effect of $\mathrm{pH}$ (a) $\mathrm{pH}=9.12$, (b) $\mathrm{pH}=7.00$, (c) $\mathrm{pH}=5.12$, (d) $\mathrm{pH}=$ 2.10 , (e) $\mathrm{pH}=3.08$

The effect of concentration of HP- $\beta$-cyclodextrin on enantiomer separation was presented in Fig. 5. When the concentration of HP- $\beta$-cyclodextrin was $0 \mathrm{mg} / \mathrm{mL}$, enantiomer separation was 0 . With an increase of the concentration of HP- $\beta$-cyclodextrin, the separation for lamivudine enantiomers decreased greatly ${ }^{6}$. Moreover, when the concentration of HP- $\beta$-cyclodextrin was $40 \mathrm{mg} / \mathrm{mL}$, its separation was 1.596 . However, as the concentration continues to increase to $60 \mathrm{mg} /$ $\mathrm{mL}$ or $70 \mathrm{mg} / \mathrm{mL}$, the separation of enantiomer was decreased greatly. Therefore, the concentration of HP- $\beta$-cyclodextrin 40 $\mathrm{mg} / \mathrm{mL}$ was selected. 

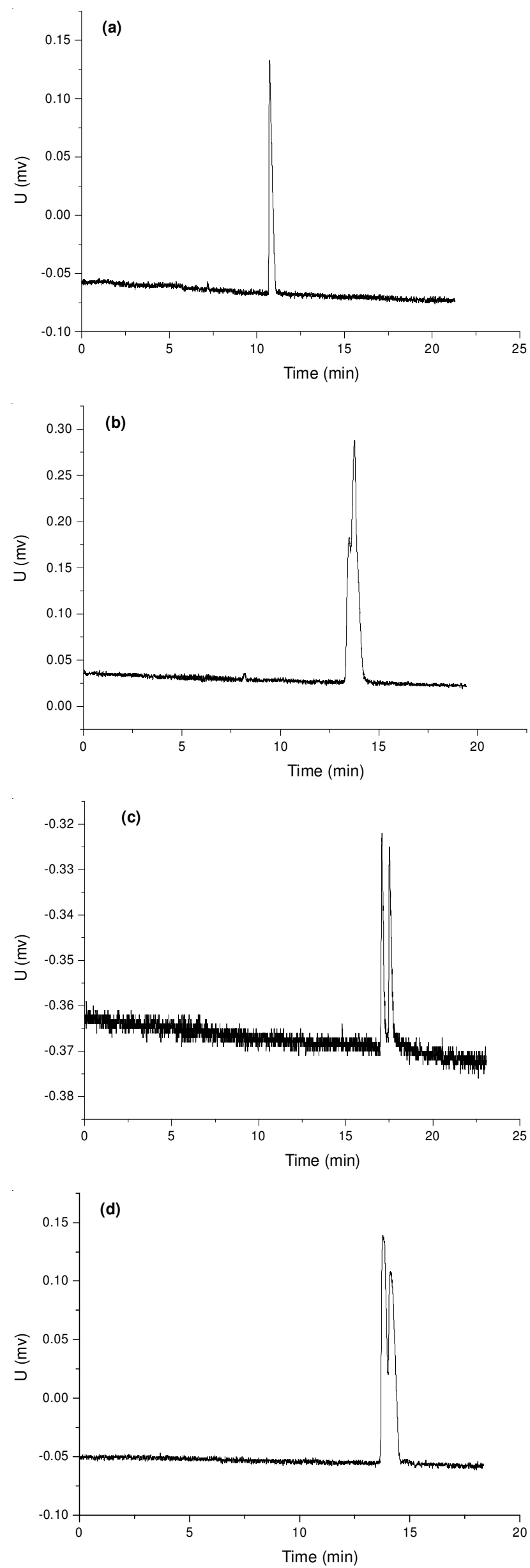

(e)

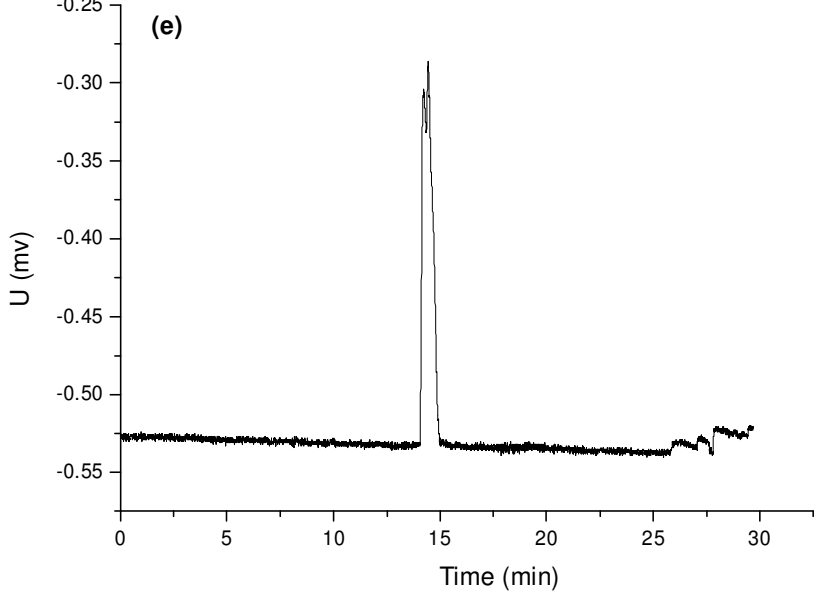

Fig. 5. Effect of HP- $\beta$-cyclodextrin concentration (a) $0 \mathrm{mg} / \mathrm{mL}$, (b) $25 \mathrm{mg} /$ $\mathrm{mL}$, (c) $40 \mathrm{mg} / \mathrm{mL}$, (d) $60 \mathrm{mg} / \mathrm{mL}$, (e) $70 \mathrm{mg} / \mathrm{mL}$

Effect of voltage: Finally, under the above selected conditions $(40 \mathrm{mg} / \mathrm{mL} \mathrm{HP}-\beta$-cyclodextrin concentration, $40 \mathrm{mmol} / \mathrm{L}$ $\mathrm{NaH}_{2} \mathrm{PO}_{4}$ and $\mathrm{pH} 3.08$ ), the influence of the applied voltage from 10 to $20 \mathrm{kV}$ was investigated. Fig. 6 depicts the electropherograms obtained for 10,15 and $20 \mathrm{kV}$. It can be observed that an increase in the separation voltage originated a decrease in the migration time and also in the resolution. However, a value of $15 \mathrm{kV}$ gave rise to the shorter migration time (16 min) with enough resolution $(\mathrm{R}=1.596)$. Then, it was the separation voltage selected to obtain a rapid enantiomeric separation of lamivudine enantiomers ${ }^{7}$.
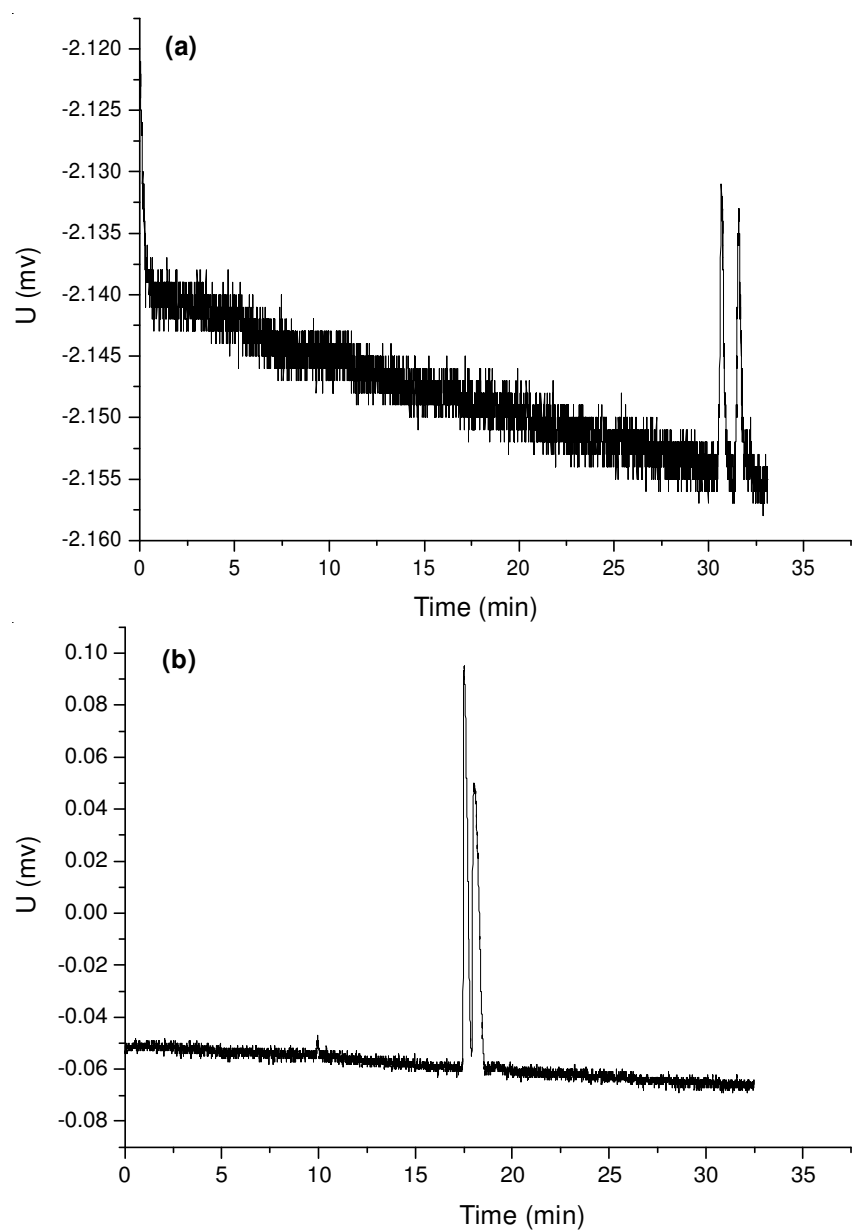


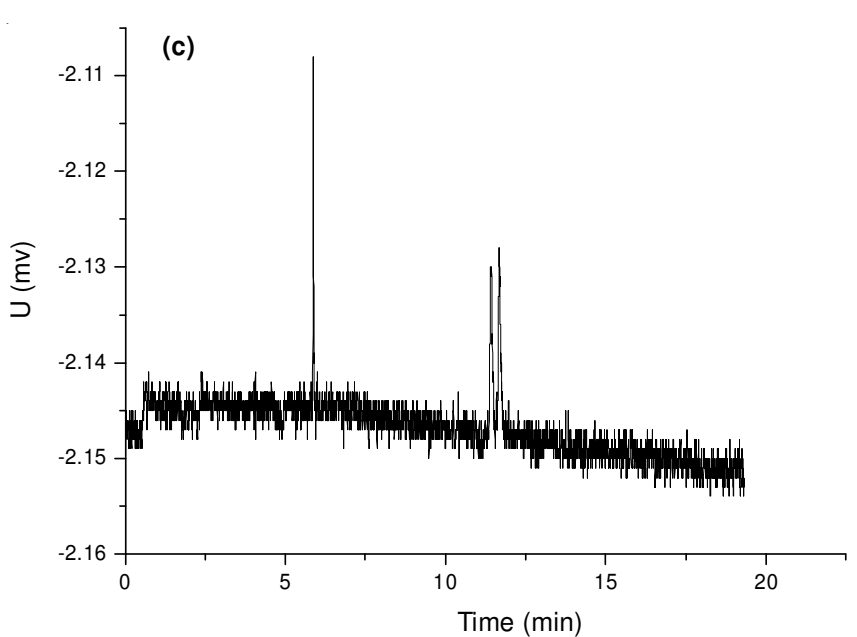

Fig. 6. Effect of voltage (a) $10 \mathrm{kV}$, (b) $15 \mathrm{kV}$, (c) $20 \mathrm{kV}$

Linearity: In $0.0625 \mathrm{mg} / \mathrm{mL} \sim 1 \mathrm{mg} / \mathrm{mL}$ range, five concentrations were collected, they were $0.0625 \mathrm{mg} / \mathrm{mL}, 0.25 \mathrm{mg}$ / $\mathrm{mL}, 0.5 \mathrm{mg} / \mathrm{mL}, 0.8 \mathrm{mg} / \mathrm{mL}, 1 \mathrm{mg} / \mathrm{mL}$. At the same time, we need map the peak area of $\mathrm{Y}$ and the concentration of $\mathrm{X}$.

For lamivudine, the correlation factor (r) is 0.9993 and the line equation is $\mathrm{Y}=10603.10 \mathrm{x}+120.75$; while for its enantiomer, the correlation factor (r) is 0.9993 and the line equation is $\mathrm{Y}=2747.23 \mathrm{x}+65.34$, both of them indicating very good linearity. The standard curves of lamivudine and its enantiomer are as follows (Fig. 7).
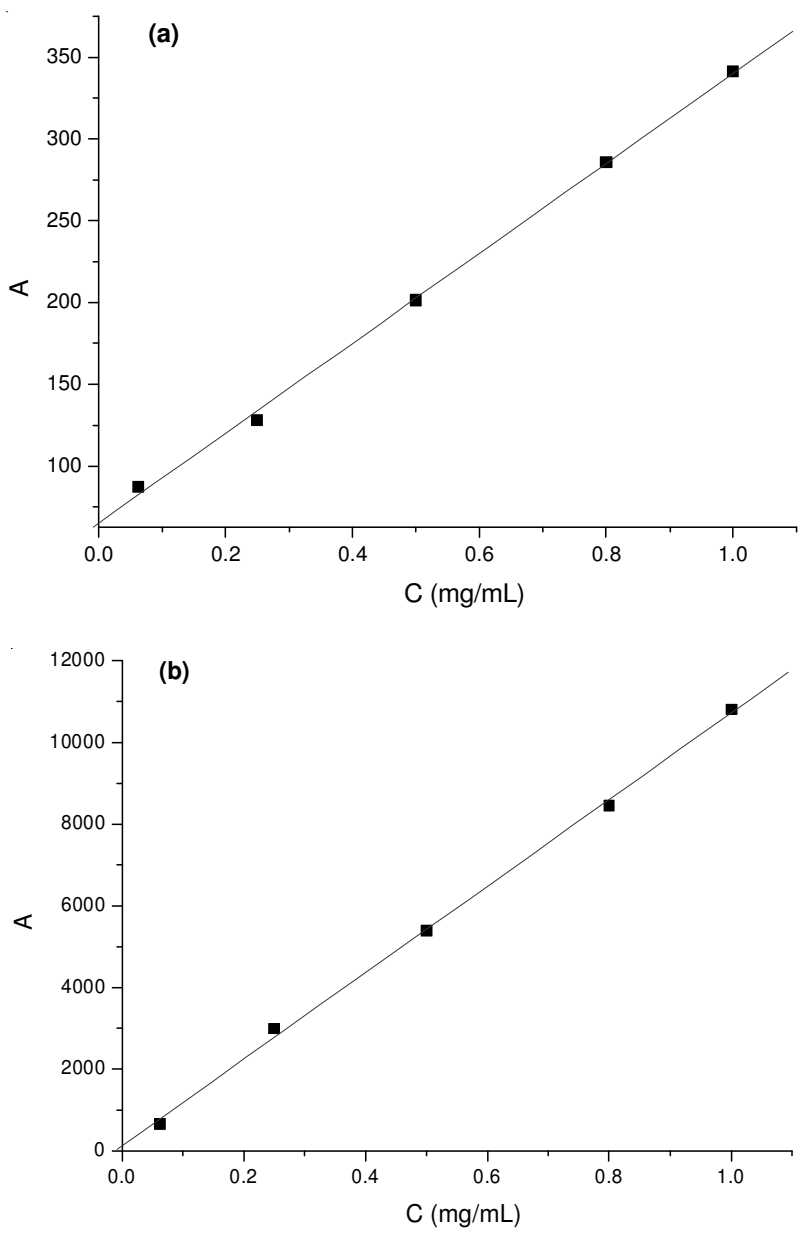

Fig. 7. Standard curves of lamivudine and its enantiomer
Recovery studies: Recovery refers to the actual measured ratio of the amount and dosage. In the experiment, we need the preparation of a concentration of 80,100 and $120 \%$. Each concentration was analyzed three times. Lamivudine average recovery was $99.71 \%$ and its enantiomer was $100.12 \%$. The results of standard addition recovery studies of lamivudine and its enantiomer were shown in Tables 1 and 2 .

\begin{tabular}{|c|c|c|c|c|c|}
\hline \multicolumn{6}{|c|}{$\begin{array}{l}\text { TABLE-1 } \\
\text { ASSARY RESULTS OF RECOVERY FOR } \\
\text { LAMIVUDINE LEVOISOMER }\end{array}$} \\
\hline & $\begin{array}{c}\text { Added } \\
(\mathrm{mg} / \mathrm{mL})\end{array}$ & $\begin{array}{l}\text { Detected } \\
(\mathrm{mg} / \mathrm{mL})\end{array}$ & $\begin{array}{c}\text { Recovery } \\
(\%)\end{array}$ & $\begin{array}{c}\text { Average } \\
(\%)\end{array}$ & $\operatorname{RSD}(\%)$ \\
\hline \multirow{3}{*}{$80 \%$} & 0.798 & 0.8 & 99.75 & \multirow{3}{*}{99.71} & \multirow{3}{*}{0.27} \\
\hline & 0.796 & 0.8 & 99.50 & & \\
\hline & 0.799 & 0.8 & 99.88 & & \\
\hline \multirow{3}{*}{$100 \%$} & 0.996 & 1.0 & 99.60 & \multirow{3}{*}{99.57} & \multirow{3}{*}{0.22} \\
\hline & 0.994 & 1.0 & 99.40 & & \\
\hline & 0.997 & 1.0 & 99.70 & & \\
\hline \multirow{3}{*}{$120 \%$} & 1.201 & 1.2 & 100.08 & \multirow{3}{*}{99.86} & \multirow{3}{*}{0.29} \\
\hline & 1.198 & 1.2 & 99.83 & & \\
\hline & 1.196 & 1.2 & 99.63 & & \\
\hline
\end{tabular}

\begin{tabular}{|c|c|c|c|c|c|}
\hline \multicolumn{6}{|c|}{$\begin{array}{c}\text { TABLE-2 } \\
\text { ASSARY RESULTS OF RECOVERY FOR } \\
\text { LAMIVUDINE DEXTROISOMER }\end{array}$} \\
\hline & $\begin{array}{c}\text { Added } \\
(\mathrm{mg} / \mathrm{mL})\end{array}$ & $\begin{array}{l}\text { Detected } \\
(\mathrm{mg} / \mathrm{mL})\end{array}$ & $\begin{array}{c}\text { Recovery } \\
(\%)\end{array}$ & $\begin{array}{c}\text { Average } \\
(\%)\end{array}$ & $\begin{array}{l}\text { RSD } \\
(\%)\end{array}$ \\
\hline \multirow{3}{*}{$80 \%$} & 0.805 & 0.8 & 100.63 & \multirow{3}{*}{100.21} & \multirow{3}{*}{0.62} \\
\hline & 0.802 & 0.8 & 100.25 & & \\
\hline & 0.798 & 0.8 & 99.75 & & \\
\hline \multirow{3}{*}{$100 \%$} & 1.007 & 1.0 & 100.70 & \multirow{3}{*}{100.27} & \multirow{3}{*}{0.64} \\
\hline & 1.003 & 1.0 & 100.30 & & \\
\hline & 0.998 & 1.0 & 99.80 & & \\
\hline \multirow{3}{*}{$120 \%$} & 1.205 & 1.2 & 100.42 & \multirow{3}{*}{99.89} & \multirow{3}{*}{0.67} \\
\hline & 1.197 & 1.2 & 99.75 & & \\
\hline & 1.194 & 1.2 & 99.50 & & \\
\hline
\end{tabular}

Detection limit and limit of quantification: The detection limit is defined as the concentration that generates signal equivalent to three times noise $(\mathrm{S} / \mathrm{N}=3)$. The detection limits for lamivudine and its enantiomer are $1.25 \mu \mathrm{g} / \mathrm{mL}$ and $2.5 \mu \mathrm{g} /$ $\mathrm{mL}$ respectively. The limit of quantification is defined as the concentration that generates signal equivalent to three times noise $(\mathrm{S} / \mathrm{N}=10)$. The limits of quantification for lamivudine and its enantiomer are $0.02 \mu \mathrm{mg} / \mathrm{mL}$ and $0.03 \mu \mathrm{mg} / \mathrm{mL}$, respectively.

Repeatability: Repeatability refers to the repeated determination of the measured values when the same volume levels consistent with each other.We measured repeatability by relative standard deviations (RSDs) and determine a good precision when $\mathrm{RSD}<2 \%$. In the study, we shoud under the same conditions for 6 experiments. The relative standard deviations (RSDs) $(n=6)$ of the peak-area of lamivudine and its enantiomer are 1.58 and $1.35 \%$ respectively.

\section{Conclusion}

A rapid, simple, efficient and cheap method has been developed for the determination of lamivudine at the same time by using high performance capillary electrophoresis method. 


\section{REFERENCES}

1. T. Tsukamoto, T. Ushio and J. Haginaka, J. Chromatogr. A, 864, 163 (1999).

2. H.X. Liu, A.M. Yu, F.Q. Liu, Y.H. Shi, L.K. Han and Y.F. Chen, J. Pharm. Biomed. Anal., 41, 1376 (2006).

3. C.F. Zhu, X.L. Lin and Y.H. Wei, J. Pharm. Biomed. Anal., 30, 293 (2002)
4. S.S. Zhou, J. Ouyang, W.R.G. Baeyens, H.C. Zhao and Y.P. Yang, J. Chromatogr. A, 1130, 296 (2006)

5. K.W. Tang, P.L. Zhang and H.J. Li, Process Biochem., 46, 1817 (2011).

6. S.Q. Tong, Y.-X. Guan, J.Z. Yan, B. Zheng and L.Y. Zhao, J. Chromatogr. A, 1218, 5434 (2011).

7. M. Castro-Puyana, M.A. García and M.L. Marina, J. Chromatogr. B, 875, 260 (2008). 